\title{
HUBUNGAN MOTIVASI KERJA TERHADAP KEPATUHAN DALAM PENGEMBALIAN BERKAS REKAM MEDIS DI SEKSI REKAM MEDIS RUMAH SAKIT UMUM DAERAH Dr. SOETOMO
}

\author{
Kanti Rakhmaningrum *Bambang Nudji* \\ *Prodi Administrasi Rumah Sakit STIKES Yayasan Rumah Sakit Dr. Soetomo, \\ kanti.rakhmaningrum1@gmail.com \\ bbnudji@gmail.com
}

\begin{abstract}
ABSTRAK
Pengembalian berkas rekam medis adalah sistem yang cukup penting di seksi rekam medis, karena pengembalian berkas rekam medis dimulai dari berkas tersebut berada diruang rawat sampai kembali ke seksi rekam medis sesuai dengan kebijakan batas waktu pengembalian yaitu 2x24 jam. Berdasarkan data evaluasi pada bulan Februari 2016 dapat dilihat adanya keterlambatan yaitu dari 3451 berkas rekam medis pasien Keluar Rumah Sakit (KRS) terdapat 859 atau sekitar $24,9 \%$ berkas rekam medis belum masuk pada seksi rekam medis. Penelitian dilakukan pada bulan Mei 2016 - Juli 2016. Jenis penelitian ini adalah deskriptif kuantitatif dengan rancangan cross sectional. Instrumen dalam penelitian ini berupa kuesioner tertutup yang ditujukan pada dokter, perawat/bidan dan petugas rekam medis di Instalasi Rawat Inap RSUD Dr. Soetomo. Sampel dalam penelitian ini yaitu 81 orang responden yang terdiri dari dokter, perawat/bidan dan petugas rekam medis. Analisis data menggunakan teknik korelasi spearman dan crosstab dengan hasil analisis menunjukkan bahwa tidak ada hubungan tanggung jawab dengan kepatuhan $(\mathrm{p}=0,388)$, tidak ada hubungan beban kerja dengan kepatuhan $(\mathrm{p}=0,206)$, tidak ada hubungan penghargaan prestasi dengan kepatuhan $(\mathrm{p}=0,213)$, namun ada hubungan motivasi dari pimpinan terhadap kepatuhan $(\mathrm{p}=0,029)$ karena dari 4 faktor motivasi yang memiliki hubungan dengan kepatuhan hanyalah 1 faktor dan 3 faktor lainnya tidak memiliki hubungan maka pada penelitian ini motivasi tidak memiliki hubungan terhadap kepatuhan $(\mathrm{p}=0,250)$. Kesimpulan dari penelitian ini adalah untuk menganalisa hubungan motivasi (meliputi: tanggung jawab, beban kerja, motivasi dari pimpinan dan penghargaan prestasi) terhadap kepatuhan pengembalian berkas rekam medis di seksi rekam medis RSUD Dr. Soetomo. Saran yang diberikan adalah lebih meningkatkan lagi tanggung jawab terhadap setiap pekerjaan, pemahaman pengetahuan tentang tupoksi yang akan berhubungan dengan beban kerja dan pemberian penghargaan berupa reward secara berkala kepada ruangan yang telah patuh dalam hal pengembalian berkas rekam medis dari ruang rawat inap ke seksi rekam medis RSUD Dr. Soetomo.
\end{abstract}

Kata kunci : Menganalisa Hubungan Motivasi, Kepatuhan Pengembalian Berkas, Rekam Medis

\section{ABSTRACT}

Returns of medical record file is a system that is quite important in the medical records section, due to the return started from the medical record file of the file in the ward to return to the section of medical records in accordance with the policy of return deadline is $2 \times 24$ hours. Based on the evaluation data on February 2016 can be seen that the delay of the patient's medical record file 3451 out hospital, there are 859 or about $24.9 \%$ medical record file has not been entered in the section on medical records. The study was conducted in May 2016 - July 2016. This type of research is quantitative descriptive with the cross-sectional 
design. Instruments in this study a closed questionnaire aimed at doctors, nurses / midwives and medical records in Inpatient room at RSUD Dr. Soetomo. The sample in this research is 81 respondents consisting of doctors, nurses / midwives and medical records. Analysis of the data used the techniques of spearman correlation and crosstab with the results of the analysis show that there is no relationship of responsibility with adherence $(p=0.388)$, there was no relationship workload with adherence $(p=0.206)$, there was no relationship achievement awards to adherence $(p=0.213)$, but there was relationship between motivation of the leadership of adherence $(p=0.029)$ because of four factors of motivation that has a relationship to compliance is just one factor and 3 other factors do not have a relationship, this research motivation has no relationship to adherence $(p=0.250)$. The conclusion of this study was to analyze the relationship between motivation (include: responsibility, workload, motivation of leadership and achievement awards) to compliance of medical record file returns in a medical record section at RSUD Dr. Soetomo. The suggestion are given to increase responsibility for each job, understanding the knowledge of the duties that would be related to the workload and the award in the form of reward periodically to the room that had been obedient in handling medical record file of the wards to the section of medical records at RSUD Dr. Soetomo.

Keywords : Analyzing the Relationships of Motivation, Compliance File Returns, Medical records

\section{LATAR BELAKANG}

Menurut Undang-Undang Republik Indonesia (UU RI) No. 44 Tahun 2009 Tentang Rumah Sakit pada pasal 1 ayat 1 menyatakan bahwa rumah sakit adalah institusi pelayanan yang menyelenggarakan pelayanan kesehatan perorangan secara paripurna yang menyediakan pelayanan rawat inap, rawat jalan, dan gawat darurat.

Rumah Sakit Umum Daerah (RSUD) Dr. Soetomo merupakan rumah sakit pemerintah yang menjadi rujukan nasional yang mempunyai visi menjadi rumah sakit yang bermutu internasional dalam pelayanan, pendidikan, dan peneliti-an serta memiliki misi menyeleng-garakan pelayanan kesehatan, pendidikan dan penelitian yang profesional, akuntabel yang ber-orientasi pada kastemer untuk menuju pelayanan kesehatan berstandar internasional.

Sebagai lembaga kesehatan yang kompleks, rumah sakit memerlukan suatu sistem informasi yang baik dalam menjalankan aktivitasnya. Dalam hal ini, RSUD Dr. Soetomo mempunyai beberapa pelayanan yang salah satunya ada pada bagian rekam medis.

Menurut Peraturan Menteri Kesehatan Republik Indonesia (Permenkes RI) No. 269 Tahun 2008 Tentang Rekam Medis, menyebutkan bahwa rekam medis adalah berkas yang berisikan catatan dan dokumen tentang identitas pasien,pemeriksaan, pengobatan tindakan dan pelayanan lain yang telah diberikan kepada pasien.

Rekam medis pada RSUD Dr. Soetomo merupakan salah satu pelayanan yang terdiri dari pelayanan rekam medis, penelitian, penyediaan data morbiditas dan mortalitas, pengodean diagnosa dan prosedur tindakan medis yang diberikan setiap hari senin-jumat jam 07.00-15.00. Dalam memberikan pelayanan medis kepada pasien wajib di buatkan suatu dokumen yang berisi setiap tindakan pelayanan medis kepada pasien tersebut secara kronologis, yang disebut dengan dokumen rekam medis.

Berdasarkan survei awal didapatkan hasil berupa data seperti pada tabel berikut ini: 
Tabel 1 Data Evaluasi Pengembalian Berkas Rekam Medis dari Instalasi Rawat Inap ke Bidang Pemasaran dan Rekam Medis Bulan Februari 2016

\begin{tabular}{|c|c|c|c|c|c|c|}
\hline \multirow{3}{*}{ NO } & \multirow{3}{*}{ INSTALASI } & \multirow{3}{*}{$\begin{array}{c}\text { PASIEN } \\
\text { KRS }\end{array}$} & \multicolumn{4}{|c|}{ BERKAS REKAM MEDIS } \\
\hline & & & \multicolumn{2}{|c|}{ MASUK } & \multicolumn{2}{|c|}{ BLM MASUK } \\
\hline & & & JML & $\%$ & JML & $\%$ \\
\hline 1 & Irna Medik & 1261 & 1167 & 92,5 & 94 & 7,5 \\
\hline 2 & Irna Anak & 489 & 470 & 96,1 & 19 & 3,9 \\
\hline 3 & Irna Jiwa & 29 & 28 & 96,6 & 1 & 3,4 \\
\hline 4 & Irna Obgyn & 546 & 398 & 72,9 & 148 & 27,1 \\
\hline 5 & Irna Bedah & 927 & 457 & 49,3 & 470 & 50,7 \\
\hline 6 & IGD & 161 & 52 & 32,3 & 109 & 67,7 \\
\hline 7 & Instalasi Rawat Intensif Dan Reanimasi & 28 & 17 & 60,7 & 11 & 39,3 \\
\hline 8 & Gigi Dan Mulut & 10 & 3 & 30,0 & 7 & 70,0 \\
\hline \multicolumn{2}{|c|}{ Jumlah } & 3451 & 2592 & 75,1 & 859 & 24,9 \\
\hline
\end{tabular}

Sumber : Laporan surat edaran dari data evaluasi di Bidang Pemasaran dan Rekam Medis RSUD Dr. Soetomo Bulan Februari 2016

Berdasarkan data pada tabel 1 dapat dilihat adanya keterlambat-an dalam pengembalian dokumen rekam medis yaitu dari 3451 berkas rekam medis pasien Keluar Rumah Sakit (KRS) terdapat 2592 atau sekitar $75,1 \%$ berkas sudah masuk pada seksi rekam medis, sedangkan ada 859 atau sekitar $24,9 \%$ berkas rekam medis belum masuk pada seksi rekam medis.

Pengembalian berkas rekam medis adalah sistem yang cukup penting di seksi rekam medis, karena pengembalian rekam medis dimulai dari berkas tersebut berada diruang rawat sampai kembali ke seksi rekam medis sesuai dengan kebijakan batas waktu pengembalian yaitu 2x24 jam. Dengan alasan tersebut, maka peneliti tertarik untuk mengambil judul Hubungan Motivasi Kerja terhadap Kepatuhan dalam Pengem-balian Berkas Rekam Medis di Seksi Rekam Medis RSUD Dr. Soetomo.

\section{BAHAN DAN METODE}

Jenis penelitian ini adalah deskriptif kuantitatif dengan ran-cangan cross sectional. Penelitian ini dilakukan untuk mengetahui hubung-an motivasi terhadap kepatuhan pengembalian berkas rekam medis dari instalasi rawat inap ke seksi rekam medis RSUD Dr. Soetomo.

Penelitian deskriptif kuantitatif adalah penelitian dengan memper-oleh data yang berbentuk angka atau data kualitatif yang diangkakan.

Rancangan cross sectional adalah rancangan penelitian dengan melakukan pengukuran atau peng-amatan pada saat bersamaan, atau melakukan pemeriksaan status pema-paran pada satu waktu dan satu kali untuk mencari hubungan antara variabel independen dan variabel dependen.

Pada saat penelitian dilakukan pengambilan data dengan instrumen kuesioner yang langsung dibagikan kepada praktisi kesehatan (dokter, perawat/bidan dan petugas rekam medis), dari hasil kuesioner tersebut akan dihitung dan dikategorikan dalam skor penilaian.

Penelitian ini dilaksanakan pada bulan Mei 2016 sampai dengan Juli 2016 di Seksi Rekam Medis RSUD Dr. Soetomo.

Dalam penelitian ini yang menjadi populasi adalah pegawai rawat inap yang terdiri dari Dokter, Perawat/Bidan dan Petugas Rekam Medis (praktisi kesehatan) 
yang tersebar pada 37 ruang rawat inap RSUD Dr. Soetomo.

Berdasarkan perhitungan sim-pel random sampling tersebut, maka dari 37 populasi yang ada dapat diambil sampel sejumlah 27 sampel ruang rawat inap dengan jumlah responden yaitu 81 pegawai yang terdiri dari Dokter, Perawat/Bidan dan Petugas Rekam Medis yang akan diteliti hubungan motivasi kerja terhadap kepatuhan pengembalian berkas rekam medis dari instalasi rawat inap ke seksi rekam medis RSUD Dr. Soetomo.

Instrumen dalam penelitian ini berupa kuesioner. Kuesioner dituju-kan pada dokter/bidan, perawat dan petugas rekam medis di instalasi rawat inap RSUD Dr. Soetomo.

Dalam penelitian ini meng-gunakan jenis kuesioner tertutup, yaitu responden diberikan kuesioner yang terdiri beberapapertanyaan yang dikelompokkan ber-dasarkan variabel independen dan variabel dependen.

Sebelum melakukan penelitian, dilakukan uji validitas dan uji reliabilitas terlebih dahulu. Teknik analisis data yang digunakan adalah analisis crosstabulasi data dan teknik korelasi.

\section{HASIL PENELITIAN}

Dari hasil penelitian "Hubung-an Motivasi terhadap Kepatuhan Pegawai dalam Kepatuhan Pengem-balian Berkas Rekam Medis d Seksi Rekam Medis RSUD Dr. Soetomo Surabaya" yang dilakukan selama bulan Mei-Juli 2016 dengan membagikan kuesioner sebagai instrumen penelitian kepada responden yaitu Dokter/Bidan, Perawat dan Petugas Rekam Medis (praktisi kesehatan) di ruangan rawat inap RSUD Dr. Soetomo didapatkan hasil bahwa dari 81 prakitisi kesehatan yang diteliti mempunyai karakteristik sebagai berikut:

1. Dari segi jenis kelamin, sebanyak 24 orang $(29,6 \%)$ berjenis kela-min Pria, sedangkan sisanya 57 orang $(70,4 \%)$ berjenis kelamin Wanita.
2. Dari segi usia, lebih banyak praktisi kesehatan berusia 20-30 tahun yaitu sekitar 37 orang $(45,7 \%), 22$ orang $(27,2 \%)$ praktisi kesehatan memiliki kate-gori usia 31-40 Tahun, 14 orang $(17,3 \%)$ praktisi kesehatan memi-liki kategori usia 41-50 Tahun dan sisanya 8 orang $(9,9 \%)$ praktisi kesehatan memiliki kategori usia $>50$ Tahun.

3. Dari segi pendidikan terakhir, terdapat 2 orang $(2,5 \%)$ praktisi kesehatan lulusan SMA/SMK, 43 orang $(53,1 \%)$ praktisi kesehatan lulusan Diploma (D1 dan D3) serta 36 orang $(44,4 \%)$ praktisi kesehatan dengan pendidikan terakhir yaitu Sarjana (S1).

4. Dari segi pekerjaan/profesi, terda-pat 25 orang $(30,9 \%)$ praktisi kesehatan berprofesi sebagai dok-ter, 28 orang $(34,6 \%)$ praktisi ke-sehatan berprofesi sebagai pera-wat, 26 orang $(32,1 \%)$ praktisi kesehatan berprofesi sebagai petu-gas rekam medis dan 2 orang $(2,5 \%)$ praktisi kesehatan ber-profesi sebagai bidan.

5. Dilihat dari karakteristik status pernikahan, terdapat 64 orang $(79 \%)$ praktisi kesehatan berstatus menikah dan 17 orang $(21 \%)$ praktisi kesehatan berstatus belum menikah.

6. Dilihat dari karakteristik lama bekerja, terdapat 7 orang $(8,6 \%)$ bekerja dibawah 1 tahun, 46 orang $(56,8 \%)$ bekerja selama 1 - 10 tahun, 18 orang $(22,2 \%)$ bekerja selama $11-20$ tahun, 8 orang $(9,9 \%)$ bekerja selama $21-30$ tahun dan 2 orang $(2,5 \%)$ bekerja diatas 30 tahun.

\section{Hubungan Tanggung Jawab terhadap Kepatuhan Pengembalian BRM di Seksi Rekam Medis RSUD Dr. Soetomo}

Tabel 2 Hubungan Tanggung Jawab terhadap Kepatuhan Pengembalian Berkas Rekam Medis di Seksi Rekam Medis RSUD Dr. Soetomo Tahun 2016

\begin{tabular}{|l|r|r|r|r|}
\hline \multirow{2}{*}{$\begin{array}{c}\text { Tanggung } \\
\text { Jawab }\end{array}$} & \multicolumn{4}{|c|}{ Kepatuhan } \\
\cline { 2 - 5 } & \multicolumn{2}{|c|}{ Patuh } & \multicolumn{2}{c|}{ Tidak Patuh } \\
\cline { 2 - 5 } & $\mathrm{N}$ & \multicolumn{1}{c|}{$\%$} & \multicolumn{1}{c|}{$\mathrm{N}$} & $\%$ \\
\hline Tinggi & 26 & 86,7 & 4 & 13,3 \\
\hline Sedang & 43 & 84,3 & 8 & 15,7 \\
\hline
\end{tabular}




\begin{tabular}{|l|r|r|r|r|}
\hline Rendah & 0 & 0 & 0 & 0 \\
\hline Total & 69 & 85,2 & 12 & 14,8 \\
\hline
\end{tabular}

Tabel 3. Nilai Signifikansi dan Kekuatan Hubungan Tanggung Jawab terhadap Kepatuhan Pengembalian Berkas Rekam Medis di Seksi Rekam Medis RSUD Dr. Soetomo Tahun 2016

\begin{tabular}{|l|l|r|}
\hline \multicolumn{2}{|c|}{ Variabel } & Kepatuhan \\
\hline \multirow{3}{*}{$\begin{array}{l}\text { Tanggung } \\
\text { Jawab }\end{array}$} & $\begin{array}{l}\text { Correlation } \\
\text { Coefficient }\end{array}$ & 0,032 \\
\cline { 2 - 3 } & Sig. (1-tailed) & 0,388 \\
\cline { 2 - 3 } & $\mathrm{N}$ & 81 \\
\hline
\end{tabular}

Kekuatan hubungan tanggung jawab dan kepatuhan adalah 0,032, maka terdapat hubungan korelasi diabaikan positif yang tidak signifikan antara tanggung jawab dan kepatuhan. Dari hasil signifikansi yaitu 0,388 lebih besar dari 0,05 maka variabel tanggung jawab tidak memiliki hubungan terhadap kepa-tuhan pengembalian berkas rekam medis di seksi rekam medis RSUD Dr. Soetomo.

Pada hasil penelitian ini didapatkan bahwa tanggung jawab tidak memiliki hubungan terhadap kepatuhan pengembalian berkas rekam medis di seksi rekam medis RSUD Dr. Soetomo dikarenakan tidak semua responden yang menjadi sampel penelitian ini bertanggung jawab dalam pengembalian, yang bertanggung jawab dalam pengem-balian adalah petugas rekam medis saja sedangkan responden yang ber-profesi sebagai dokter/bidan dan perawat tidak bertanggung jawab dengan kepatuhan pengembalian berkas rekam medis namun ada hubungannya dengan pengisian kelengkapan berkas rekam medis di ruang rawat inap.

Berdasarkan keterangan diatas, sebaiknya praktisi kesehatan seperti dokter dan perawat/bidan juga memiliki rasa tanggung jawab yang tinggi terhadap kelengkapan pengisi-an berkas rekam medis yang nanti-nya akan berhubungan dengan kepa-tuhan petugas rekam medis dalam hal pengembalian berkas rekam medis dari ruangan rawat inap ke seksi rekam medis RSUD Dr. Soetomo.

\section{Hubungan Beban Kerja terhadap Kepatuhan Pengembalian BRM di Seksi Rekam Medis RSUD Dr. Soetomo}

Tabel 4. Hubungan Beban Kerja Terhadap Kepatuhan Pengembalian Berkas Rekam Medis di Seksi Rekam Medis RSUD Dr. Soetomo Tahun 2016

\begin{tabular}{|c|c|c|c|c|}
\hline \multirow{2}{*}{ Beban Kerja } & \multicolumn{4}{|c|}{ Kepatuhan } \\
\cline { 2 - 5 } & \multicolumn{2}{|c|}{ Patuh } & \multicolumn{2}{c|}{ Tidak Patuh } \\
\cline { 2 - 5 } Tinggi & 7 & 77,8 & 2 & $\begin{array}{c}22, \\
2\end{array}$ \\
\hline Sedang & 60 & 85,7 & 10 & $\begin{array}{c}14, \\
3\end{array}$ \\
\hline Rendah & 2 & 100 & 0 & 0 \\
\hline Total & 69 & 85,2 & 12 & $\begin{array}{c}14, \\
8\end{array}$ \\
\hline Signifikansi & \multicolumn{4}{|c|}{$0,206>0,05$} \\
\hline
\end{tabular}

Tabel 5. Nilai Signifikansi dan Kekuatan Hubungan Beban Kerja terhadap Kepatuhan Pengembalian Berkas Rekam Medis di Seksi Rekam Medis RSUD Dr. Soetomo Tahun 2016

\begin{tabular}{|l|l|r|}
\hline \multicolumn{2}{|c|}{ Variabel } & Kepatuhan \\
\hline $\begin{array}{l}\text { Beaban } \\
\text { Kerja }\end{array}$ & $\begin{array}{l}\text { Correlation } \\
\text { Coefficient }\end{array}$ & $-0,093$ \\
\cline { 2 - 3 } & Sig. (1-tailed) & 0,206 \\
\cline { 2 - 3 } & $\mathrm{N}$ & 81 \\
\hline
\end{tabular}

Kekuatan hubungan beban kerja dan kepatuhan adalah -0,093, maka terdapat hubungan korelasi diabaikan negatif yang tidak signifi-kan antara beban kerja dan kepatuh-an. Dari hasil signifikansi yaitu 0,206 lebih besar dari 0,05 maka variabel beban kerja tidak memiliki hubungan terhadap kepatuhan pengembalian berkas rekam medis di seksi rekam medis RSUD Dr. Soetomo.

Pada hasil penelitian ini didapatkan bahwa beban kerja tidak memiliki hubungan terhadap kepa-tuhan pengembalian berkas rekam medis di seksi rekam medis RSUD Dr. Soetomo dikarenakan tidak se-mua responden yang menjadi sampel penelitian ini memiliki beban kerja yang sama, setiap profesi (dokter, perawat/bidan dan petugas rekam medis) memiliki beban kerja yang tidak sama yang akan berhubungan dalam 
kepatuhan pengembalian berkas rekam medis namun ada hubungannya dengan pengisian kelengkapan berkas rekam medis di ruang rawat inap.

Menurut Suma'mur (2009) beban kerja menentukan berapa lama seseorang dapat bekerja sesuai dengan kapasitas kerjanya. Sese-orang yang bekerja dengan beban kerja yang terlalu berat yang tidak sebanding dengan kapasitas kerjanya maka dapat menyebabkan terjadinya kelelahan. Energi yang dibutuhkan akan semakin banyak apabila otot semakin lama berkontraksi melawan beban yang diperolehnya. Energi pemulihan saat relaksasi yang tidak sebanding menyebabkan timbulnya kelelahan.

\section{Hubungan Motivasi dari Pimpinan terhadap Kepatuhan Pengembali-an BRM di Seksi Rekam Medis RSUD Dr. Soetomo}

Tabel 6 Hubungan Motivasi dari Pimpinan Terhadap Kepatuhan Pengembalian Berkas Rekam Medis di Seksi Rekam Medis RSUD/ Dr. Soetomo Tahun 2016

\begin{tabular}{|l|r|r|r|r|}
\hline \multirow{2}{*}{$\begin{array}{c}\text { Motivasi dari } \\
\text { Pimpinan }\end{array}$} & \multicolumn{4}{|c|}{ Kepatuhan } \\
\cline { 2 - 5 } & \multicolumn{2}{|c|}{ Patuh } & \multicolumn{1}{c|}{ Tidak Patuh } \\
\cline { 2 - 5 } & N & \multicolumn{1}{c|}{ \% } & \multicolumn{1}{c|}{ N } \\
\hline Tinggi & 20 & 95,2 & 1 & 4,8 \\
\hline Sedang & 0 & 83,1 & 10 & 16,9 \\
\hline Rendah & 69 & 0 & 1 & 100 \\
\hline Total & 65,2 & 12 & 14,8 \\
\hline Signifikansi & $0,029<0,05$ \\
\hline
\end{tabular}

Tabel 7 Nilai Signifikansi dan Kekuatan

Hubungan Motivasi dari Pimpinan terhadap Kepatuhan Pengembalian Berkas

Rekam Medis di Seksi Rekam Medis

RSUD Dr. Soetomo Tahun 2016

\begin{tabular}{|c|c|c|}
\hline \multicolumn{2}{|c|}{ Variabel } & Kepatuhan \\
\hline \multirow{3}{*}{$\begin{array}{l}\text { Motivasi } \\
\text { dari } \\
\text { Pimpinan }\end{array}$} & $\begin{array}{l}\text { Correlation } \\
\text { Coefficient }\end{array}$ & 0,212 \\
\hline & Sig. (1-tailed) & 0,029 \\
\hline & $\mathrm{N}$ & 81 \\
\hline
\end{tabular}

Kekuatan hubungan motivasi dari pimpinan dan kepatuhan adalah 0,212, maka terdapat hubungan korelasi rendah positif yang signifi-kan antara motivasi dari pimpinan dan kepatuhan. Dari hasil signifikan-si yaitu 0,029 lebih kecil dari 0,05 maka variabel motivasi dari pimpinan memiliki hubungan terhadap kepatuhan pengembalian berkas re-kam medis di seksi rekam medis RSUD Dr. Soetomo.

Pada hasil penelitian ini didapatkan bahwa motivasi dari pimpinan memiliki hubungan terhadap kepatuhan pengembalian berkas rekam medis di seksi rekam medis RSUD Dr. Soetomo dikarena-kan semua responden yang menjadi sampel penelitian ini akan diperlakukan sama dan mendapat motivasi dari pimpinan yang sama dalam satu ruangan sehingga motivasi dari pimpinan akan mempengaruhi pegawai dalam kepatuhan pengem-balian berkas berkas rekam medis di seksi rekam medis RSUD Dr. Soetomo.

\section{Hubungan Penghargaan Prestasi terhadap Kepatuhan Pengembali-an BRM di Seksi Rekam Medis RSUD Dr. Soetomo}

Tabel 8. Hubungan Penghargaan Prestasi terhadap Kepatuhan Pengembalian Berkas Rekam Medis di Seksi Rekam Medis RSUD Dr. Soetomo Tahun 2016

\begin{tabular}{|l|r|c|r|c|}
\hline \multirow{2}{*}{$\begin{array}{c}\text { Penghargaan } \\
\text { Prestasi }\end{array}$} & \multicolumn{4}{|c|}{ Kepatuhan } \\
\cline { 2 - 5 } & \multicolumn{3}{|c|}{ Patuh } & \multicolumn{2}{c|}{ Tidak Patuh } \\
\cline { 2 - 5 } Tinggi & \multicolumn{1}{|c|}{$\%$} & \multicolumn{1}{c|}{ N } & $\%$ \\
\hline Sedang & 58 & 80,0 & 1 & 10,0 \\
\hline Rendah & 2 & 66,7 & 10 & 14,7 \\
\hline Total & 69 & 85,2 & 12 & 33,3 \\
\hline Signifikansi & \multicolumn{6}{|c|}{$0,213>0,05$} & 14,8 \\
\hline
\end{tabular}

Tabel 9. Nilai Signifikansi dan Kekuatan Hubungan Penghargaan Prestasi terhadap Kepatuhan Pengembalian Berkas Rekam Medis di Seksi Rekam Medis RSUD

Dr.Soetomo Tahun 2016

\begin{tabular}{|l|l|r|}
\hline \multicolumn{2}{|c|}{ Variabel } & Kepatuhan \\
\hline $\begin{array}{l}\text { Penghargaan } \\
\text { Prestasi }\end{array}$ & $\begin{array}{l}\text { Correlation } \\
\text { Coefficient }\end{array}$ & 0,090 \\
\cline { 2 - 3 } & Sig. (1-tailed) & 0,213 \\
\cline { 2 - 3 } & $\mathrm{N}$ & 81 \\
\hline
\end{tabular}

Kekuatan hubungan penghar-gaan prestasi dan kepatuhan adalah 0,090, maka terdapat hubungan korelasi diabaikan positif yang 
tidak signifikan antara penghargaan prestasi dan kepatuhan. Dari hasil signifikansi yaitu 0,213 lebih besar dari 0,05 maka variabel penghargaan prestasi tidak memiliki hubungan terhadap kepatuhan pengembalian berkas rekam medis di seksi rekam medis RSUD Dr. Soetomo.

Pada hasil penelitian ini didapatkan bahwa penghargaan prestasi tidak memiliki hubungan terhadap kepatuhan pengembalian berkas rekam medis di seksi rekam medis RSUD Dr. Soetomo dikarena-kan tidak semua responden yang menjadi sampel penelitian ini akan mendapat penghargaan prestasi da-lam hal kepatuhan dalam pengem-balian berkas rekam medis di seksi rekam medis RSUD Dr. Soetomo.

Berdasarkan keterangan diatas, untuk menjaga kepatuhan petugas rekam medis dalam hal pengem-balian berkas rekam medis ke seksi rekam medis RSUD Dr. Soetomo yang berhubungan dengan penghar-gaan prestasi yaitu diberikan peng-hargaan secara bergilir setiap tahunnya kepada ruangan yang patuh mengembalikan berkas tidak lebih dari $2 \times 24$ jam. Hal ini dilakukan untuk memotivasi para praktisi kesehatan supaya bekerja sesuai dengan peraturan atau kebijakan rumah sakit yang berlaku.

\section{Hubungan Motivasi Kerja terhadap Kepatuhan Pengembali-an BRM di Seksi Rekam Medis RSUD Dr. Soetomo}

Tabel 10. Hubungan Motivasi Kerja Terhadap Kepatuhan Pengembalian

Berkas Rekam Medis di Seksi Rekam Medis RSUD Dr. Soetomo Tahun 2016

\begin{tabular}{|l|r|r|r|r|}
\hline \multirow{2}{*}{ Motivasi } & \multicolumn{4}{|c|}{ Kepatuhan } \\
\cline { 2 - 5 } & \multicolumn{2}{|c|}{ Patuh } & \multicolumn{1}{c|}{ Tidak Patuh } \\
\cline { 2 - 5 } & $\mathrm{N}$ & \multicolumn{1}{c|}{$\%$} & \multicolumn{1}{c|}{ N } & \multicolumn{1}{c|}{$\%$} \\
\hline Tinggi & 11 & 91,7 & 1 & 8,3 \\
\hline Sedang & 58 & 84,1 & 11 & 15,9 \\
\hline Rendah & 0 & 0 & 0 & 0 \\
\hline Total & 69 & 85,2 & 12 & 14,8 \\
\hline Signifikansi & \multicolumn{6}{|c|}{$0,250>0,05$} \\
\hline
\end{tabular}

Tabel 11. Nilai SignifikansiMdan

Kekuatan Hubungan Motivasi Kerja terhadap Kepatuhan Pengembalian Berkas

Rekam Medis di Seksi Rekam Medis RSUD Dr. Soetomo Tahun 2016

\begin{tabular}{|l|l|r|}
\hline \multicolumn{2}{|c|}{ Variabel } & \multicolumn{1}{c|}{ Kepatuhan } \\
\hline Motivasi & Correlation & 0,076 \\
Kerja & Coefficient & \\
\cline { 2 - 3 } & Sig. (1-tailed) & 0,250 \\
\cline { 2 - 3 } & N & 81 \\
\hline
\end{tabular}

Kekuatan hubungan penghar-gaan prestasi dan kepatuhan adalah 0,076, maka terdapat hubungan korelasi sedang yang tidak signifikan antara motivasi dan kepatuhan. Dari hasil signifikansi yaitu 0,250 lebih besar dari 0,05 maka variabel penghargaan prestasi tidak memiliki hubungan terhadap kepatuhan pengembalian berkas rekam medis di seksi rekam medis RSUD Dr. Soetomo.

Pada hasil penelitian ini didapatkan bahwa motivasi tidak memiliki hubungan terhadap kepatuhan pengembalian berkas rekam medis di seksi rekam medis RSUD Dr. Soetomo dikarenakan dari faktorfaktor motivasi yang terdiri dari tanggung jawab, beban kerja, motivasi dari pimpinan dan penghargaan prestai, hanya motivasi dari pimpinan saja yang mempunyai hubungan terhadap kepatuhan dan faktor yang lainnya tidak mempunyai hubungan.

\section{KESIMPULAN}

1. Tidak ada hubungan tanggung jawab dengan kepatuhan pengembalian berkas rekam medis di Seksi Rekam Medis RSUD Dr.Soetomo.

2. Tidak ada hubungan beban kerja dengan kepatuhan pengembalian berkas rekam medis di Seksi Rekam Medis RSUD Dr.Soetomo.

3. Ada hubungan motivasi dari pimpinan dengan kepatuhan pengembalian berkas rekam medis di Seksi Rekam Medis RSUD Dr.Soetomo.

4. Tidak ada hubungan penghargaan prestasi dengan kepatuhan pengembalian berkas rekam medis di 
Seksi Rekam Medis RSUD Dr.Soetomo.

5. Tidak ada hubungan motivasi (meliputi: tanggung jawab, beban kerja, motivasi dari pimpinan dan penghargaan prestasi) dengan kepatuhan pengembalian berkas rekam medis di Seksi Rekam Medis RSUD Dr.Soetomo.

\section{SARAN}

1. Pegawai yang tidak berhubungan langsung dengan kepatuhan pengembalian berkas rekam medis seharusnya juga mempunyai tanggung jawab terhadap faktor-faktor yang mempengaruhi patuh dan tidak patuhnya pengembalian berkas yaitu dengan memiliki rasa tanggung jawab terhadap pengisi-an kelengkapan berkas rekam me-dis sehingga petugas rekam medis akan patuh dalam pengembalian berkas rekam medis dari rawat inap ke seksi rekam medis RSUD Dr. Soetomo.

2. Beban kerja yang belum sesuai dengan setiap pekerjaan yang dilakukan membuat responden yang berhubungan dengan kelengkapan berkas rekam medis (dokter dan perawat/bidan) terlambat dalam mengisi berkas sehingga berhubungan juga de-ngan ketidakpatuhan pengem-balian berkas rekam medis dari rawat inap ke seksi rekam medis RSUD Dr. Soetomo. Dalam hal ini, sebaiknya pegawai lebih diberi pengetahuan lagi tentang tupoksi pekerjaan nya di ruangan rawat inap.

3. Penghargaan prestasi yang jarang diberikan kepada pegawai yang berprestasi akan berhubungan dengan kepatuhan dalam pengembalian berkas rekam medis, pegawai akan merasa dihargai atas prestasi dan kerja nya apabila mendapatkan peng-hargaan prestasi. Dalam hal ini sebaiknya diberikan reward secara berkala terhadap ruangan rawat inap yang telah patuh dalam pe-ngembalian berkas rekam medis di seksi rekam medis RSUD Dr. Soetomo.

4. Motivasi dari pimpinan khususnya motivasi dari kepala ruangan diharapkan lebih menyeluruh kepada seluruh praktisi kesehatan yang ada di ruangan, agar terjalin kerjasama yang baik yang akan berhubungan dengan kepatuhan pengembalian berkas rekam medis.

5. Untuk penelitian selanjutnya, sebelum melihat kepatuhan petu-gas rekam medis dalam pengem-balian berkas rekam medis di Sek-si Rekam Medis, sebaiknya dipas-tikan dulu bahwa praktisi kese-hatan lain yang berpsofesi sebagai dokter, perawat/bidan sudah me-lengkapi pengisian berkas rekam medis.

\section{DAFTAR PUSTAKA}

Arif, 2013. Pengaruh Motivasi Terhadap Produktivitas Kerja: Studi Kasus Pada PT $\mathrm{X}$ Bandung. Journal The WINNERS Vol. 14 No. 2 September 2013: 77-86. Politeknik PIKSI Ganesha Bandung.

Arifin, 2004. Pengaruh Moivasi dan kemampuan kerja terhadap kinerja dan kepuasan kerja karyawan PT SAT Nusa Persada di Batam. Tesis. Universitas Airlangga Surabaya.

Depkes RI Dirjen Pelayanan Medis, 2006. Buku Pedoman Pelayanan Medis Rumah Sakit di Indonesia Revisi II. Jakarta: Dirjen Yanmed Depkes RI.

Hastono, S.P., 2001. Analisis Data. Jakarta: Pustaka Fakultas Kesehatan Masyarakat Universitas Indonesia.

Hidayat, A. Aziz Alimul, 2010, Metode Penelitian Kesehatan Paradigma Kuantitatif. Surabaya: Health Books Publishing.

Hidayat, Anwar. Regresi Logistik. http://www.statistikiklan.com/2015/02/reg resi-logistik.html?m=1 (diakses 05 Juni 2016).

Kadarisman, 2012. Manajemen Pengembangan Sumber Daya Manusia. Jakarta: Raja Grafindo Persada. 
Keputusan Menteri Kesehatan Republik Indonesia (Kepmenkes RI) No. 1204 Tahun 2004 Tentang Persyaratan Kesehatan Lingkungan Rumah Sakit. Jakarta: Departemen Kesehatan.

Keputusan Menteri Negara Pendayagunaan Aparatur Negara Republik Indonesia No. 135 Tahun 2002 Tentang Jabatan Fungsional Perekam Medis dan Angka Kreditnya. Jakarta: Departemen RI Notoatmodjo, Soekidjo, 2003. Pendidikan dan Perilaku Kesehatan. Jakarta: Rineka Cipta.

Peraturan Menteri Kesehatan Republik Indonesia No. 269 Tahun 2008 Tentang Rekam Medis. Jakarta: Departemen Kesehatan.

Peraturan Menteri Kesehatan Republik Indonesia No. 340 Tahun 2010 Tentang Klasifikasi Rumah Sakit. Jakarta: Departemen Kesehatan.

Rangkuti, Freddy, 2004, The power of brands: Teknik mengelola brand equity dan strategi pengembangan merek plus analisa kasus dengan SPSS. Jakarta: PT Gramedia Pustaka Utama.

Ridwan, 2005. Skala Pengukuran Variabel-Variabel Penelitian. Bandung: Alfabeta.

Rustyanto, Ery, 2009. Etika Profesi Perekam Medis dan Informasi Kesehatan. Yogyalarta: Graha Ilmu.

Samaji, Iji, 2007. Pengaruh tingkat kualitas kerja pegawai dalam pelayanan perpajakan terhadap tingkat kepatuhan pengusaha kena pajak (studi pada kantor pelyanan pajak sidoarjo timur dan sidoarjo barat. Tesis. Program Magister AkuntansiPerpajakan Program Pascasarjana, Universitas Airlangga Surabaya.

Sofyan Yamin dan Heri Kurniawan, 2009. SPSS COMPLETE Teknik Analisis Statistik Terlengkap dengan Software SPSS. Jakarta: Salemba Infotek.

Supriyanto, Rangkuman MK II Manajemen Berkas dan Isi Rekam Medis. http://www.academia.edu/3275264/Manaj emen_Berkas_dan_Isi_Rekam_Medis (diakses 05 Juni 2016).
Undang-Undang Republik Indonesia No. 44 Tahun 2009 Tentang Rumah Sakit. Jakarta: Menteri Hukum dan Hak Asasi Manusia Republik Indonesia Disahkan pada tanggal 28 Oktober 2009.

Winarti, 2013. Analisis Kelengkaan Pengisian dan Pengembalian Rekam Medis Rawat Inap Rumah Sakit. Jurnal Administrasi Kesehatan Indonesia Volume 1 No. 4 September-Desember 2013. Universitas Airlangga Surabaya.

Yulia, 2009. Analisis Kelengkapan Pengisian Resume Medis Pada Pasien Rawat Inap di RSIA Budi Kemuliaan. Jurnal. Universitas Indonesia Jakarta.

Republik Indonesia. 2009. UndangUndang Republik Indonesia No. 44. Rumah Sakit. Presiden Republik Indonesia 28 Oktober 2009. Menteri Hukum dan Hak Asasi Manusia Republik Indonesia 28 Oktober 2009. Lembar Negara Republik Indonesia Tahun 2009 No. 153. Jakarta.

Yunizar, A., Fauzan, A., 2014. Sistem pengelolaan limbah padat pada RS. Dr. H. Moch. Anasari Saleh Banjarmasin. Jurnal Manajemen Sistem Volume 1 No.1, hal 59. 